\title{
Humanized Mouse Models of Staphylococcus aureus Infection
}

\author{
Dane Parker* \\ Department of Pediatrics, Columbia University, New York, NY, USA
}

Staphylococcus aureus is a successful human pathogen that has adapted itself in response to selection pressure by the human immune system. A commensal of the human skin and nose, it is a leading cause of several conditions: skin and soft tissue infection, pneumonia, septicemia, peritonitis, bacteremia, and endocarditis. Mice have been used extensively in all these conditions to identify virulence factors and host components important for pathogenesis. Although significant effort has gone toward development of an anti-staphylococcal vaccine, antibodies have proven ineffective in preventing infection in humans after successful studies in mice. These results have raised questions as to the utility of mice to predict patient outcome and suggest that humanized mice might prove useful in modeling infection. The development of humanized mouse models of S. aureus infection will allow us to assess the contribution of several human-specific virulence factors, in addition to exploring components of the human immune system in

OPEN ACCESS

Edited by:

Ramesh Akkina,

Colorado State University, USA

Reviewed by:

Vijay Panchanathan,

Perdana University, Malaysia

Fabio Bagnoli,

GlaxoSmithKline, Italy

*Correspondence:

Dane Parker

dp2375@columbia.edu

Specialty section:

This article was submitted to

Vaccines and Molecular

Therapeutics,

a section of the journal

Frontiers in Immunology

Received: 13 March 2017

Accepted: 18 April 2017

Published: 04 May 2017

Citation:

Parker D (2017) Humanized Mouse

Models of Staphylococcus aureus Infection.

Front. Immunol. 8:512.

doi: 10.3389/fimmu.2017.00512 protection against $S$. aureus infection. Their use is discussed in light of several recently reported studies.

Keywords: Staphylococcus aureus, humanized mouse, pneumonia, lung, sepsis, skin, mouse model, infection

\section{Staphylococcus aureus}

Staphylococcus aureus is a Gram-positive pathogen that can exist as a commensal on skin. It is a human pathogen and a leading cause of skin and soft tissue infections, pneumonia, endocarditis, and osteomyelitis $(1,2)$. In particular, methicillin-resistant S. aureus (MRSA) is a major problem not only in the hospital setting but also in the community causing significant economic burden (3-5). MRSA strains are twice as likely to kill and cost the US economy in excess of \$4 billion/ year (6-8). In contrast to hospital-acquired strains, community-acquired strains of $S$. aureus infect otherwise healthy individuals. The MRSA strain USA300 $(4,9,10)$ infects healthy, hospitalized, and post-influenza patients in the context of pneumonia (11-14), is the dominant clone, and is epidemic in the United States. Secondary bacterial infection post-influenza is a leading cause of morbidity and mortality (15-17), which has been shown for history's major pandemics, and S. aureus is one of the most common pathogens $(12,18,19)$. This is of increasing concern as the population ages, as they are at increased risk of influenza infection. Colonization of the nose with $S$. aureus is relatively common with up to $30 \%$ of the population being persistent carriers, while the proportion colonized with MRSA is increasing (20-23). Carriage increases the risk of infection $(24,25)$, and as a result of this, patients are often decolonized prior to surgery to prevent infection (26).

\section{MOUSE MODELS OF INFECTION}

Studies investigating the pathogenesis of $S$. aureus infection have relied heavily on the use of mouse models. Mice have been used to understand the role virulence factors play during infection as well 
as the contribution of specific host pathways and factors in the response to $S$. aureus. Mouse models for several important clinical diseases have been developed, including: peritonitis $(27,28)$, pneumonia (29-31), sepsis (32), skin and soft tissue infection $(33,34)$, endocarditis $(35,36)$, abscesses $(37,38)$, osteomyelitis $(39,40)$, arthritis $(41)$, and nasal colonization (42-44).

Mice possess a number of attributes that make them desirable in modeling infection. They are small in size, do not occupy significant space, are cheap, reproduce rapidly, and have similar immune, nervous, cardiovascular, and endocrine systems to humans (45-47). Another major advantage is their genetic tractability. In mice, genes can be readily inactivated "knocked out," genes inserted "knocked in," gene reporter fusions integrated into the genome, and tissue specific mutations developed. This genetic utility makes them attractive to study host immune factors important in infection. However, the use of mice is not without their limitations. Many features of mice are significantly different from humans, such as their small size, altered metabolic rate, fatty acid composition of cells, higher rates of reactive oxygen species generation and thus oxidative damage, different diet, microbiome, and typically being inbred (48). There has also been some controversy recently on how well mice correlate with human inflammatory stresses based on transcriptional profiling and pathway analyses (49-51).

\section{WHY DO WE NEED HUMANIZED MICE FOR S. aureus INFECTION?}

Although mice have proven extremely useful in determining the role of many $S$. aureus virulence factors and identifying host pathways that contribute to infection, they have been unable to predict success for vaccine candidates in humans $(52,53)$. This disconnect between the mouse model and efficacy in humans supports the conclusion that the mouse lacks all the necessary components to truly model S. aureus infection. It has also become increasingly apparent that $S$. aureus produces a number of virulence factors that have high species specificity toward the human molecular counterpart that they target.

One major group of proteins that possess human specificity are the bi-component toxins (54). Panton-Valentine leukocidin (PVL; LukSF), LukAB, and HlgCB, all preferentially target the human version of their receptor. PVL and $\mathrm{HlgCB}$ target the $\mathrm{C} 5 \mathrm{aR}$ receptor, while LukAB targets $\mathrm{CD} 11 \mathrm{~b}$ (55). PVL does have some activity toward the rabbit version of the receptor; however, the other two toxins display only high specificity toward the human equivalent. The $S$. aureus superantigens/enterotoxins also show much greater affinity toward human cells, with vastly higher doses of protein required to invoke a response in mice $(56,57)$. S. aureus produces a large array of surface proteins required for its adherence to proteins encountered on the mucosal surface. Some of these surface proteins also display specificity toward their human counterpart, such as SdrG for human fibrinogen, Fnbp for fibronectin, and IsdB for hemoglobin (58). There are also likely to be several other yet-to-be-identified proteins that have human specificity based on the fact that $S$. aureus is a human-adapted pathogen. Thus, the development of a model that actually possesses the correct receptor targets and cells for these virulence factors to be investigated would be advantageous. The presence of an immune system to better model the human immune response would also no doubt prove useful in future vaccine development as well as gaining an improved understanding of the host-pathogen interaction in the context of $S$. aureus infection.

The host specificity of $S$. aureus toward human proteins has already been investigated in the context of superantigens and iron acquisition. It has been observed with the staphylococcal superantigens that HLA class II molecules control the superantigenic response and that this response is significantly reduced in non-human (including mice) models. A trend in this field has been to utilize knock-in mice expressing the appropriate HLA molecule for the superantigen (enterotoxin) under study. This has included HLA-DR3, HLA-DR4, and CD4 knock-in mice (59-63). Studies conducted using these mice have shown a significant increase in the immune response, indicative of the increased sensitivity of these cells to the superantigens. The preference for human hemoglobin over other mammal's hemoglobin has been observed and is dependent upon the staphylococcal hemoglobin receptor IsdB. S. aureus grows better in the presence of human hemoglobin when iron is limited and the expression of human hemoglobin in mice leads to increased susceptibility to $S$. aureus infection (64). Thus, evidence already exists that warrants humanizing mice would improve the capacity to model S. aureus infection.

\section{HUMANIZED MICE}

The use of humanized mice has only relatively recently become prevalent. Their use was accelerated through the development of the NSG mouse (non-obese diabetic/severe combined immunodeficient mouse with a null mutation in the IL2R common gamma chain) (65). These mice lack B, T, and NK cells, complement, and have defective myeloid cells $(65,66)$. The NSG mice have been observed to possess the most efficient engraftment rates and support human hemato-lymphopoiesis (66-68). The mice are typically generated through the transfer of human $\mathrm{CD} 4^{+}$stem cells (69). Additionally, the implantation of human fetal liver/thymus tissue under the kidney capsule improves T cell development $(70,71)$. Humanized mice have been shown to evoke a human immune response to infection. The combinatorial diversity on their $\mathrm{T}$ cell receptors and IgG fully replicates the human samples that are used to populate the mice (72). Humanized mice have been utilized in the study of several viral pathogens such as EBV, HIV, and Dengue, as well as Malaria and Salmonella (73-76). Recently, a succession of studies has investigated the utility of these mice in the study of $S$. aureus pathogenesis.

\section{RECENT DEVELOPMENTS WITH S. aureus AND HUMANIZED MICE}

The first study to investigate the utility of humanized mice with $S$. aureus highlighted their increased susceptibility to infection. 
Knop et al. (77) conducted intraperitoneal infections in humanized mice generated from irradiated NSG pups transferred with CD $34^{+}$cells. Humanized mice displayed significantly increased mortality compared to their controls. While non-reconstituted NSG mice did display some residual toxicity from radiation, the addition of human cells was shown to confer the lethality seen with the humanized mice. Increased bacterial counts were also observed in several organs; lungs, spleen, kidneys, liver, brain, and the bone marrow. The T cells in the humanized mice showed evidence of activation (CD69 expression), Fas receptor expression, and increased apoptosis after infection. Analysis of the human cells indicated a large proportion of B cells, followed by $\mathrm{T}$ cells and myeloid cells. Levels of chimerism were highest in the spleen $(60 \%)$ and bone marrow (50\%), 30\% in the peripheral blood and $<20 \%$ in the peritoneal exudate. This study indicated that humanized mice could be useful in modeling $S$. aureus infection, and subsequent studies have built on this to investigate the role of human-specific virulence factors.

The second study to utilize humanized mice with $S$. aureus investigated their utility in the context of skin infection, also showing an increased susceptibility to infection (78). In a subcutaneous model of infection, 10- to 100 -fold less organisms were required to cause analogous disease pathology in non-humanized mice. Tseng et al. (78) found no differences in bacterial clearance or cytokine production. The phenotype observed was pathological, indicating that cellular toxicity did not influence bacterial clearance. The size of the skin lesions also correlated to the levels of chimerism in the mice, larger lesions were observed in mice with a higher percentage of human $\mathrm{CD} 45^{+}$cells. This model was then used to investigate the role of PVL in infection. PVL has a controversial role in infection. Conflicting epidemiological reports and animal studies exist, partly due to the fact many animal studies were performed prior to the identification of its receptor, $\mathrm{C} 5 \mathrm{aR}$, and its high preference for the human version of this receptor (79-87). The expression of PVL led to larger areas of dermonecrosis. This effect was due to its ability to target and kill neutrophils, as transfer of human neutrophils alone to NSG mice was able to recapitulate this phenotype. While the authors successfully showed a role for PVL in skin infection with molecular Koch's postulates, a PVL inhibitor in vivo was unable to reduce disease severity. Like the first study, this work also utilized stem cell transfer into neonate NSG mice and observed similar levels of engraftment in the spleen. This work proved the utility for the humanized mouse in delineating the functions of staphylococcal virulence factors as well as its usefulness as a model for skin infection.

The third and most recent humanized mouse study showcased the utility of these mice for respiratory infection (71). As in the previous studies, the humanized mice displayed a significant increase in susceptibility to infection. Compared to the standard mouse strains C57BL/6J, NOD and murinized controls (NSG mice transferred with murine bone marrow), the humanized mice contained bacterial burdens 40 -fold higher. The role of PVL was also investigated in this pulmonary model and was shown to contribute to infection, using both bacterial mutants and neutralizing antibody (71). The presence of PVL led to increased bacterial burden, increased lung pathology and decreased cytokine production. The target of PVL appeared to be the macrophage, with increased numbers present in mice infected with the PVL-deficient strain. The NSG transgenic mouse with human Il3 and Csf2 knocked in has improved macrophage reconstitution compared to the standard NSG humanized mouse (88). Consistent with human macrophages conferring the increased susceptibility, the use of these additional knock-in mice had even higher levels of bacteria present in the airways and lung tissue. While a role for PVL in pulmonary infection was identified, this was not the case for another human-specific toxin LukAB, which displayed no phenotype in this model (71). This study differed from the previous two in its use of adult mice and the implantation of thymus tissue under the kidney capsule. This was apparent in the higher levels of $\mathrm{T}$ cells present among the human $\mathrm{CD} 45^{+}$population, approximately $50 \%$ in the lung (71). What these three studies do show is that irrespective of the inoculation site the humanized mice had an increased susceptibility to infection, which will only improve as better humanized mouse models are generated.

\section{FUTURE MODELS}

The development of improved humanized mouse models will further increase the susceptibility and hence sensitivity of modeling S. aureus infections in vivo. This will be achieved through improved overall reconstitution of the human immune system, improved differentiation, and development of myeloid subsets, as well at the improved expression of neutrophils, an integral cell type particularly in pneumonia and skin infection models. Significant work has already been done in this area with the insertion of $C s f 1, C s f 2$, and $I l 3$ into mice, leading to improved differentiation of macrophages and alveolar macrophages, respectively $(88,89)$. The knocking in of Csf2 and Il3 was shown to increase the susceptibility of $S$. aureus in the context of acute pneumonia (71). Further studies have shown that the integration of thrombopoietin enhances maintenance and multilineage differentiation and insertion of signal-regulatory protein alpha prevents phagocytosis of the human cells by the remnant murine immune system $(90,91)$. Additional transgenics appropriate to $S$. aureus would include a combination of the aforementioned along with: human HLA types for the study of superantigens (92), insertion of human toll-like receptors for the innate immune response (75), as well as the incorporation of epithelial cells in the lung and skin for mucosal models $(34,93)$ and red blood cells for systemic studies $(94,95)$. These developments will facilitate adequate modeling of a broad range of $S$. aureus human-specific virulence factors.

\section{CONCLUSION}

Staphylococcus aureus is a significant human pathogen that has long been modeled in mice. Studies to-date in mice have delineated the roles of various bacterial and host factors important in infection; however, data on potential vaccine candidates identified in these models have not had similar success in human studies. Recent studies utilizing humanized mice have illuminated their utility in models of peritonitis, skin and soft tissue infection, 
and pneumonia. Researchers have shown humanized mice have increased susceptibility to $S$. aureus and in skin and pneumonia models a role for PVL in infection has been identified. As the next generation of humanized mouse models are developed, the capacity for modeling $S$. aureus will only improve. Humanized mice will facilitate determining the role of virulence factors with human host specificity and hopefully provide a system whereby potential vaccine candidate translate efficacy to humans.

\section{REFERENCES}

1. King MD, Humphrey BJ, Wang YF, Kourbatova EV, Ray SM, Blumberg HM. Emergence of community-acquired methicillin-resistant Staphylococcus aureus USA 300 clone as the predominant cause of skin and soft-tissue infections. Ann Intern Med (2006) 144(5):309-17. doi:10.7326/0003-4819-144-5200603070-00005

2. Talan DA, Krishnadasan A, Gorwitz RJ, Fosheim GE, Limbago B, Albrecht V, et al. Comparison of Staphylococcus aureus from skin and soft-tissue infections in US emergency department patients, 2004 and 2008. Clin Infect Dis (2011) 53(2):144-9. doi:10.1093/cid/cir308

3. Mizgerd JP. Lung infection - a public health priority. PLoS Med (2006) 3(2):e76. doi:10.1371/journal.pmed.0030076

4. Klevens RM, Morrison MA, Nadle J, Petit S, Gershman K, Ray S, et al. Invasive methicillin-resistant Staphylococcus aureus infections in the United States. JAMA (2007) 298(15):1763-71. doi:10.1001/jama.298.15.1763

5. Mizgerd JP. Respiratory infection and the impact of pulmonary immunity on lung health and disease. Am J Respir Crit Care Med (2012) 186(9):824-9. doi:10.1164/rccm.201206-1063PP

6. Shorr AF, Tabak YP, Gupta V, Johannes RS, Liu LZ, Kollef MH. Morbidity and cost burden of methicillin-resistant Staphylococcus aureus in early onset ventilator-associated pneumonia. Crit Care (2006) 10(3):R97. doi:10.1186/ cc4934

7. Klein E, Smith DL, Laxminarayan R. Hospitalizations and deaths caused by methicillin-resistant Staphylococcus aureus, United States, 1999-2005. Emerg Infect Dis (2007) 13(12):1840-6. doi:10.3201/eid1312.070629

8. Lee BY, Singh A, David MZ, Bartsch SM, Slayton RB, Huang SS, et al. The economic burden of community-associated methicillin-resistant Staphylococcus aureus (CA-MRSA). Clin Microbiol Infect (2013) 19(6):528-36. doi:10.1111/ j.1469-0691.2012.03914.x

9. CDC. From the Centers for Disease Control and Prevention. Public health dispatch: outbreaks of community-associated methicillin-resistant Staphylococcus aureus skin infections - Los Angeles County, California, 2002-2003. JAMA (2003) 289(11):1377.

10. McDougal LK, Steward CD, Killgore GE, Chaitram JM, McAllister SK, Tenover FC. Pulsed-field gel electrophoresis typing of oxacillin-resistant Staphylococcus aureus isolates from the United States: establishing a national database. J Clin Microbiol (2003) 41(11):5113-20. doi:10.1128/JCM.41.11. 5113-5120.2003

11. Francis JS, Doherty MC, Lopatin U, Johnston CP, Sinha G, Ross T, et al. Severe community-onset pneumonia in healthy adults caused by methicillin-resistant Staphylococcus aureus carrying the Panton-Valentine leukocidin genes. Clin Infect Dis (2005) 40(1):100-7. doi:10.1086/427148

12. Hageman JC, Uyeki TM, Francis JS, Jernigan DB, Wheeler JG, Bridges CB, et al. Severe community-acquired pneumonia due to Staphylococcus aureus, 2003-04 influenza season. Emerg Infect Dis (2006) 12(6):894-9. doi:10.3201/ eid1206.051141

13. Centers for Disease Control and Prevention. Bacterial coinfections in lung tissue specimens from fatal cases of 2009 pandemic influenza A (H1N1) United States, May-August 2009. MMWR Morb Mortal Wkly Rep (2009) 58(38):1071-4.

14. Tasher D, Stein M, Simoes EA, Shohat T, Bromberg M, Somekh E. Invasive bacterial infections in relation to influenza outbreaks, 2006-2010. Clin Infect Dis (2011) 53(12):1199-207. doi:10.1093/cid/cir726

15. Morens DM, Taubenberger JK, Fauci AS. Predominant role of bacterial pneumonia as a cause of death in pandemic influenza: implications for pandemic influenza preparedness. J Infect Dis (2008) 198(7):962-70. doi:10.1086/591708

\section{AUTHOR CONTRIBUTIONS}

DP conceived and wrote the manuscript.

\section{FUNDING}

This work was supported by the American Lung Association (RG-310706) and NIH (R56HL12565).

16. Chertow DS, Memoli MJ. Bacterial coinfection in influenza: a grand rounds review. JAMA (2013) 309(3):275-82. doi:10.1001/jama.2012.194139

17. Papanicolaou G. Severe influenza and $S$. aureus pneumonia: for whom the bell tolls? Virulence (2013) 4(8):666-68. doi:10.4161/viru.26957

18. Louria DB, Blumenfeld HL, Ellis JT, Kilbourne ED, Rogers DE. Studies on influenza in the pandemic of 1957-1958. II. Pulmonary complications of influenza. J Clin Invest (1959) 38(1 Pt 2):213-65. doi:10.1172/ JCI103791

19. Murray RJ, Robinson JO, White JN, Hughes F, Coombs GW, Pearson JC, et al. Community-acquired pneumonia due to pandemic A(H1N1)2009 influenzavirus and methicillin resistant Staphylococcus aureus co-infection. PLoS One (2010) 5(1):e8705. doi:10.1371/journal.pone.0008705

20. Creech CB II, Kernodle DS, Alsentzer A, Wilson C, Edwards KM. Increasing rates of nasal carriage of methicillin-resistant Staphylococcus aureus in healthy children. Pediatr Infect Dis J (2005) 24(7):617-21. doi:10.1097/01.inf. 0000168746.62226.a4

21. Finelli L, Fiore A, Dhara R, Brammer L, Shay DK, Kamimoto L, et al. Influenzaassociated pediatric mortality in the United States: increase of Staphylococcus aureus coinfection. Pediatrics (2008) 122(4):805-11. doi:10.1542/peds. 2008-1336

22. Gorwitz RJ, Kruszon-Moran D, McAllister SK, McQuillan G, McDougal LK, Fosheim GE, et al. Changes in the prevalence of nasal colonization with Staphylococcus aureus in the United States, 2001-2004. J Infect Dis (2008) 197(9):1226-34. doi:10.1086/533494

23. Rafee Y, Abdel-Haq N, Asmar B, Salimnia T, Pharm CV, Rybak Pharm MJ, et al. Increased prevalence of methicillin-resistant Staphylococcus aureus nasal colonization in household contacts of children with community acquired disease. BMC Infect Dis (2012) 12:45. doi:10.1186/1471-2334-12-45

24. Wertheim HF, Vos MC, Ott A, van Belkum A, Voss A, Kluytmans JA, et al. Risk and outcome of nosocomial Staphylococcus aureus bacteraemia in nasal carriers versus non-carriers. Lancet (2004) 364(9435):703-5. doi:10.1016/ S0140-6736(04)16897-9

25. Stevens AM, Hennessy T, Baggett HC, Bruden D, Parks D, Klejka J. Methicillin-resistant Staphylococcus aureus carriage and risk factors for skin infections, Southwestern Alaska, USA. Emerg Infect Dis (2010) 16(5):797-803. doi:10.3201/eid1605.091851

26. Diller R, Sonntag AK, Mellmann A, Grevener K, Senninger N, Kipp F, et al Evidence for cost reduction based on pre-admission MRSA screening in general surgery. Int J Hyg Environ Health (2008) 211(1-2):205-12. doi:10.1016/j. ijheh.2007.06.001

27. Sandberg A, Hessler JH, Skov RL, Blom J, Frimodt-Moller N. Intracellular activity of antibiotics against Staphylococcus aureus in a mouse peritonitis model. Antimicrob Agents Chemother (2009) 53(5):1874-83. doi:10.1128/ AAC.01605-07

28. Rauch S, DeDent AC, Kim HK, Bubeck Wardenburg J, Missiakas DM, Schneewind O. Abscess formation and alpha-hemolysin induced toxicity in a mouse model of Staphylococcus aureus peritoneal infection. Infect Immun (2012) 80(10):3721-32. doi:10.1128/IAI.00442-12

29. Gomez MI, Lee A, Reddy B, Muir A, Soong G, Pitt A, et al. Staphylococcus aureus protein A induces airway epithelial inflammatory responses by activating TNFR1. Nat Med (2004) 10(8):842-8. doi:10.1038/nm1079

30. Bubeck Wardenburg J, Patel RJ, Schneewind O. Surface proteins and exotoxins are required for the pathogenesis of Staphylococcus aureus pneumonia. Infect Immun (2007) 75(2):1040-4. doi:10.1128/IAI.01313-06

31. Parker D, Prince A. Staphylococcus aureus induces type I IFN signaling in dendritic cells via TLR9. J Immunol (2012) 189(8):4040-6. doi:10.4049/ jimmunol.1201055 
32. Powers ME, Bubeck Wardenburg J. Igniting the fire: Staphylococcus aureus virulence factors in the pathogenesis of sepsis. PLoS Pathog (2014) 10(2): e1003871. doi:10.1371/journal.ppat.1003871

33. Miller LS, O'Connell RM, Gutierrez MA, Pietras EM, Shahangian A, Gross CE, et al. MyD88 mediates neutrophil recruitment initiated by IL-1R but not TLR2 activation in immunity against Staphylococcus aureus. Immunity (2006) 24(1):79-91. doi:10.1016/j.immuni.2005.11.011

34. Soong G, Paulino F, Wachtel S, Parker D, Wickersham M, Zhang D, et al. Methicillin-resistant Staphylococcus aureus adaptation to human keratinocytes. MBio (2015) 6(2):e00289-15. doi:10.1128/mBio.00289-15

35. Gibson GW, Kreuser SC, Riley JM, Rosebury-Smith WS, Courtney CL, Juneau PL, et al. Development of a mouse model of induced Staphylococcus aureus infective endocarditis. Comp Med (2007) 57(6):563-9.

36. Panizzi P, Nahrendorf M, Figueiredo JL, Panizzi J, Marinelli B, Iwamoto Y, et al. In vivo detection of Staphylococcus aureus endocarditis by targeting pathogen-specific prothrombin activation. Nat Med (2011) 17(9):1142-6. doi:10.1038/nm.2423

37. Cheng AG, Kim HK, Burts ML, Krausz T, Schneewind O, Missiakas DM. Genetic requirements for Staphylococcus aureus abscess formation and persistence in host tissues. FASEB J (2009) 23(10):3393-404. doi:10.1096/fj. 09-135467

38. Cheng AG, McAdow M, Kim HK, Bae T, Missiakas DM, Schneewind O. Contribution of coagulases towards Staphylococcus aureus disease and protective immunity. PLoS Pathog (2010) 6(8):e1001036. doi:10.1371/journal. ppat. 1001036

39. Horst SA, Hoerr V, Beineke A, Kreis C, Tuchscherr L, Kalinka J, et al. A novel mouse model of Staphylococcus aureus chronic osteomyelitis that closely mimics the human infection: an integrated view of disease pathogenesis. Am J Pathol (2012) 181(4):1206-14. doi:10.1016/j.ajpath.2012.07.005

40. Cassat JE, Hammer ND, Campbell JP, Benson MA, Perrien DS, Mrak LN, et al. A secreted bacterial protease tailors the Staphylococcus aureus virulence repertoire to modulate bone remodeling during osteomyelitis. Cell Host Microbe (2013) 13(6):759-72. doi:10.1016/j.chom.2013.05.003

41. Bremell T, Lange S, Yacoub A, Ryden C, Tarkowski A. Experimental Staphylococcus aureus arthritis in mice. Infect Immun (1991) 59(8): 2615-23.

42. Lijek RS, Luque SL, Liu Q, Parker D, Bae T, Weiser JN. Protection from the acquisition of Staphylococcus aureus nasal carriage by cross-reactive antibody to a pneumococcal dehydrogenase. Proc Natl Acad Sci U S A (2012) 109(34):13823-8. doi:10.1073/pnas.1208075109

43. Xu SX, Kasper KJ, Zeppa JJ, McCormick JK. Superantigens modulate bacterial density during Staphylococcus aureus nasal colonization. Toxins (Basel) (2015) 7(5):1821-36. doi:10.3390/toxins7051821

44. Planet PJ, Parker D, Cohen TS, Smith H, Leon JD, Ryan C, et al. Lambda interferon restructures the nasal microbiome and increases susceptibility to Staphylococcus aureus superinfection. MBio (2016) 7(1):e01939-15. doi:10.1128/mBio.01939-15

45. Buer J, Balling R. Mice, microbes and models of infection. Nat Rev Genet (2003) 4(3):195-205. doi:10.1038/nrg1019

46. Rosenthal N, Brown S. The mouse ascending: perspectives for human-disease models. Nat Cell Biol (2007) 9(9):993-9. doi:10.1038/ncb437

47. Perlman RL. Mouse models of human disease: an evolutionary perspective. Evol Med Public Health (2016) 2016(1):170-6. doi:10.1093/emph/eow014

48. Xiao L, Feng Q, Liang S, Sonne SB, Xia Z, Qiu X, et al. A catalog of the mouse gut metagenome. Nat Biotechnol (2015) 33(10):1103-8. doi:10.1038/ nbt. 3353

49. Seok J, Warren HS, Cuenca AG, Mindrinos MN, Baker HV, Xu W, et al. Genomic responses in mouse models poorly mimic human inflammatory diseases. Proc Natl Acad Sci U S A (2013) 110(9):3507-12. doi:10.1073/ pnas. 1222878110

50. Warren HS, Tompkins RG, Moldawer LL, Seok J, Xu W, Mindrinos MN, et al. Mice are not men. Proc Natl Acad Sci U S A (2014) 112(4):E345. doi:10.1073/ pnas. 1414857111

51. Takao K, Miyakawa T. Genomic responses in mouse models greatly mimic human inflammatory diseases. Proc Natl Acad Sci US A (2015) 112(4):1167-72. doi:10.1073/pnas.1401965111

52. Bagnoli F, Bertholet S, Grandi G. Inferring reasons for the failure of Staphylococcus aureus vaccines in clinical trials. Front Cell Infect Microbiol (2012) 2:16. doi:10.3389/fcimb.2012.00016
53. Fowler VG, Allen KB, Moreira ED, Moustafa M, Isgro F, Boucher HW, et al. Effect of an investigational vaccine for preventing Staphylococcus aureus infections after cardiothoracic surgery: a randomized trial. JAMA (2013) 309(13):1368-78. doi:10.1001/jama.2013.3010

54. Alonzo F III, Torres VJ. Bacterial survival amidst an immune onslaught: the contribution of the Staphylococcus aureus leukotoxins. PLoS Pathog (2013) 9(2):e1003143. doi:10.1371/journal.ppat.1003143

55. DuMont AL, Yoong P, Day CJ, Alonzo F III, McDonald WH, Jennings MP, et al. Staphylococcus aureus LukAB cytotoxin kills human neutrophils by targeting the CD11b subunit of the integrin Mac-1. Proc Natl Acad Sci U S A (2013) 110(26):10794-9. doi:10.1073/pnas.1305121110

56. Lambris JD, Ricklin D, Geisbrecht BV. Complement evasion by human pathogens. Nat Rev Microbiol (2008) 6(2):132-42. doi:10.1038/nrmicro1824

57. Spaulding AR, Salgado-Pabon W, Kohler PL, Horswill AR, Leung DY, Schlievert PM. Staphylococcal and streptococcal superantigen exotoxins. Clin Microbiol Rev (2013) 26(3):422-47. doi:10.1128/CMR.00104-12

58. Foster TJ, Geoghegan JA, Ganesh VK, Hook M. Adhesion, invasion and evasion: the many functions of the surface proteins of Staphylococcus aureus. Nat Rev Microbiol (2014) 12(1):49-62. doi:10.1038/nrmicro3161

59. Yeung RS, Penninger JM, Kundig T, Khoo W, Ohashi PS, Kroemer G, et al. Human CD4 and human major histocompatibility complex class II (DQ6) transgenic mice: supersensitivity to superantigen-induced septic shock. Eur J Immunol (1996) 26(5):1074-82. doi:10.1002/eji.1830260518

60. Xu SX, Gilmore KJ, Szabo PA, Zeppa JJ, Baroja ML, Haeryfar SM, et al. Superantigens subvert the neutrophil response to promote abscess formation and enhance Staphylococcus aureus survival in vivo. Infect Immun (2014) 82(9):3588-98. doi:10.1128/IAI.02110-14

61. Karau MJ, Tilahun ME, Krogman A, Osborne BA, Goldsby RA, David CS, et al. Passive therapy with humanized anti-staphylococcal enterotoxin B antibodies attenuates systemic inflammatory response and protects from lethal pneumonia caused by staphylococcal enterotoxin B-producing Staphylococcus aureus. Virulence (2016):1-12. doi:10.1080/21505594.2016.1267894

62. Szabo PA, Goswami A, Memarnejadian A, Mallett CL, Foster PJ, McCormick JK, et al. Swift intrahepatic accumulation of granulocytic myeloid-derived suppressor cells in a humanized mouse model of toxic shock syndrome. J Infect Dis (2016) 213(12):1990-5. doi:10.1093/infdis/jiw050

63. Szabo PA, Rudak PT, Choi J, Xu SX, Schaub R, Singh B, et al. Invariant NKT cells are pathogenic in the HLA-DR4-transgenic humanized mouse model of toxic shock syndrome and can be targeted to reduce morbidity. J Infect Dis (2016) 215(5):824-29. doi:10.1093/infdis/jiw646

64. Pishchany G, McCoy AL, Torres VJ, Krause JC, Crowe JE Jr, Fabry ME, et al. Specificity for human hemoglobin enhances Staphylococcus aureus infection. Cell Host Microbe (2010) 8(6):544-50. doi:10.1016/j.chom.2010. 11.002

65. Ishikawa F, Yasukawa M, Lyons B, Yoshida S, Miyamoto T, Yoshimoto G, et al. Development of functional human blood and immune systems in NOD/ SCID/IL2 receptor \{gamma\} chain(null) mice. Blood (2005) 106(5):1565-73. doi:10.1182/blood-2005-02-0516

66. Shultz LD, Lyons BL, Burzenski LM, Gott B, Chen X, Chaleff S, et al. Human lymphoid and myeloid cell development in NOD/LtSz-scid IL2R gamma null mice engrafted with mobilized human hemopoietic stem cells. J Immunol (2005) 174(10):6477-89. doi:10.4049/jimmunol.174.10.6477

67. McDermott SP, Eppert K, Lechman ER, Doedens M, Dick JE. Comparison of human cord blood engraftment between immunocompromised mouse strains. Blood (2010) 116(2):193-200. doi:10.1182/blood-2010-02-271841

68. Tanaka S, Saito Y, Kunisawa J, Kurashima Y, Wake T, Suzuki N, et al. Development of mature and functional human myeloid subsets in hematopoietic stem cell-engrafted NOD/SCID/IL2rgammaKO mice. J Immunol (2012) 188(12):6145-55. doi:10.4049/jimmunol.1103660

69. Lan P, Tonomura N, Shimizu A, Wang S, Yang YG. Reconstitution of a functional human immune system in immunodeficient mice through combined human fetal thymus/liver and CD34+ cell transplantation. Blood (2006) 108(2):487-92. doi:10.1182/blood-2005-11-4388

70. Namikawa R, Weilbaecher KN, Kaneshima H, Yee EJ, McCune JM. Longterm human hematopoiesis in the SCID-hu mouse. J Exp Med (1990) 172(4): 1055-63. doi:10.1084/jem.172.4.1055

71. Prince A, Wang H, Kitur K, Parker D. Humanized mice exhibit increased susceptibility to Staphylococcus aureus pneumonia. J Infect Dis (2016). doi:10.1093/infdis/jiw425 
72. Marodon G, Desjardins D, Mercey L, Baillou C, Parent P, Manuel M, et al. High diversity of the immune repertoire in humanized NOD.SCID. gamma c-/- mice. Eur J Immunol (2009) 39(8):2136-45. doi:10.1002/eji. 200939480

73. Morosan S, Hez-Deroubaix S, Lunel F, Renia L, Giannini C, Van Rooijen N, et al. Liver-stage development of Plasmodium falciparum, in a humanized mouse model. J Infect Dis (2006) 193(7):996-1004. doi:10.1086/500840

74. Shultz LD, Brehm MA, Garcia-Martinez JV, Greiner DL. Humanized mice for immune system investigation: progress, promise and challenges. Nat Rev Immunol (2012) 12(11):786-98. doi:10.1038/nri3311

75. Brehm MA, Wiles MV, Greiner DL, Shultz LD. Generation of improved humanized mouse models for human infectious diseases. J Immunol Methods (2014) 410:3-17. doi:10.1016/j.jim.2014.02.011

76. Siu E, Ploss A. Modeling malaria in humanized mice: opportunities and challenges. Ann N Y Acad Sci (2015) 1342:29-36. doi:10.1111/nyas.12618

77. Knop J, Hanses F, Leist T, Archin NM, Buchholz S, Glasner J, et al. Staphylococcus aureus infection in humanized mice: a new model to study pathogenicity associated with human immune response. J Infect Dis (2015) 212(3):435-44. doi:10.1093/infdis/jiv073

78. Tseng CW, Biancotti JC, Berg BL, Gate D, Kolar SL, Muller S, et al. Increased susceptibility of humanized NSG mice to Panton-Valentine leukocidin and Staphylococcus aureus skin infection. PLoS Pathog (2015) 11(11):e1005292. doi:10.1371/journal.ppat.1005292

79. Lina G, Piemont Y, Godail-Gamot F, Bes M, Peter MO, Gauduchon V, et al. Involvement of Panton-Valentine leukocidin-producing Staphylococcus aureus in primary skin infections and pneumonia. Clin Infect Dis (1999) 29(5):1128-32. doi:10.1086/313461

80. Gillet Y, Issartel B, Vanhems P, Fournet JC, Lina G, Bes M, et al. Association between Staphylococcus aureus strains carrying gene for Panton-Valentine leukocidin and highly lethal necrotising pneumonia in young immunocompetent patients. Lancet (2002) 359(9308):753-9. doi:10.1016/S0140-6736(02) 07877-7

81. Bubeck Wardenburg J, Bae T, Otto M, Deleo FR, Schneewind O. Poring over pores: alpha-hemolysin and Panton-Valentine leukocidin in Staphylococcus aureus pneumonia. Nat Med (2007) 13(12):1405-6. doi:10.1038/ nm1207-1405

82. Labandeira-Rey M, Couzon F, Boisset S, Brown EL, Bes M, Benito Y, et al. Staphylococcus aureus Panton-Valentine leukocidin causes necrotizing pneumonia. Science (2007) 315(5815):1130-3. doi:10.1126/science.1137165

83. Villaruz AE, Bubeck Wardenburg J, Khan BA, Whitney AR, Sturdevant DE, Gardner DJ, et al. A point mutation in the agr locus rather than expression of the Panton-Valentine leukocidin caused previously reported phenotypes in Staphylococcus aureus pneumonia and gene regulation. J Infect Dis (2009) 200(5):724-34. doi:10.1086/604728

84. Diep BA, Chan L, Tattevin P, Kajikawa O, Martin TR, Basuino L, et al. Polymorphonuclear leukocytes mediate Staphylococcus aureus PantonValentine leukocidin-induced lung inflammation and injury. Proc Natl Acad Sci U S A (2010) 107(12):5587-92. doi:10.1073/pnas.0912403107

85. Shallcross LJ, Williams K, Hopkins S, Aldridge RW, Johnson AM, Hayward AC. Panton-Valentine leukocidin associated staphylococcal disease: a cross-sectional study at a London hospital, England. Clin Microbiol Infect (2010) 16(11): 1644-8. doi:10.1111/j.1469-0691.2010.03153.x

86. Diep BA, Gillet Y, Etienne J, Lina G, Vandenesch F. Panton-Valentine leucocidin and pneumonia. Lancet Infect Dis (2013) 13(7):566. doi:10.1016/ S1473-3099(13)70102-6

87. Shallcross LJ, Fragaszy E, Johnson AM, Hayward AC. The role of the Panton-Valentine leucocidin toxin in staphylococcal disease: a systematic review and meta-analysis. Lancet Infect Dis (2013) 13(1):43-54. doi:10.1016/ S1473-3099(12)70238-4

88. Willinger T, Rongvaux A, Takizawa H, Yancopoulos GD, Valenzuela DM, Murphy AJ, et al. Human IL-3/GM-CSF knock-in mice support human alveolar macrophage development and human immune responses in the lung. Proc Natl Acad Sci U S A (2011) 108(6):2390-5. doi:10.1073/pnas.1019682108

89. Rathinam C, Poueymirou WT, Rojas J, Murphy AJ, Valenzuela DM, Yancopoulos GD, et al. Efficient differentiation and function of human macrophages in humanized CSF-1 mice. Blood (2011) 118(11):3119-28. doi:10.1182/ blood-2010-12-326926

90. Strowig T, Rongvaux A, Rathinam C, Takizawa H, Borsotti C, Philbrick W, et al. Transgenic expression of human signal regulatory protein alpha in Rag2-/-gamma(c)-/- mice improves engraftment of human hematopoietic cells in humanized mice. Proc Natl Acad Sci U S A (2011) 108(32):13218-23. doi:10.1073/pnas.1109769108

91. Rongvaux A, Willinger T, Martinek J, Strowig T, Gearty SV, Teichmann LL, et al. Development and function of human innate immune cells in a humanized mouse model. Nat Biotechnol (2014) 32(4):364-72. doi:10.1038/nbt.2858

92. Akkina R. Human immune responses and potential for vaccine assessment in humanized mice. Curr Opin Immunol (2013) 25(3):403-9. doi:10.1016/j. coi.2013.03.009

93. Rosen C, Shezen E, Aronovich A, Klionsky YZ, Yaakov Y, Assayag M, et al. Preconditioning allows engraftment of mouse and human embryonic lung cells, enabling lung repair in mice. Nat Med (2015) 21(8):869-79. doi:10.1038/ nm.3889

94. Arnold L, Tyagi RK, Meija P, Swetman C, Gleeson J, Perignon JL, et al. Further improvements of the P. falciparum humanized mouse model. PLoS One (2011) 6(3):e18045. doi:10.1371/journal.pone.0018045

95. Amaladoss A, Chen Q, Liu M, Dummler SK, Dao M, Suresh S, et al. De novo generated human red blood cells in humanized mice support Plasmodium falciparum infection. PLoS One (2015) 10(6):e0129825. doi:10.1371/journal. pone.0129825

Conflict of Interest Statement: The author declares that the research was conducted in the absence of any commercial or financial relationships that could be construed as a potential conflict of interest.

Copyright (C) 2017 Parker. This is an open-access article distributed under the terms of the Creative Commons Attribution License (CC BY). The use, distribution or reproduction in other forums is permitted, provided the original author(s) or licensor are credited and that the original publication in this journal is cited, in accordance with accepted academic practice. No use, distribution or reproduction is permitted which does not comply with these terms. 